\title{
Inhabiting Flower Worlds: The Botanical Art of Madeleine Françoise Basseporte
}

Une artiste en résidence dans le monde des fleurs: L'art botanique de Madeleine Françoise Basseporte

\section{Natania Meeker and Antónia Szabari}

\section{(2) OpenEdition}

\section{Journals}

Electronic version

URL: http://journals.openedition.org/aes/757

DOI: 10.4000/aes.757

ISSN: 2258-093X

Publisher

Laboratoire LISAA

\section{Electronic reference}

Natania Meeker and Antónia Szabari, «Inhabiting Flower Worlds: The Botanical Art of Madeleine

Françoise Basseporte», Arts et Savoirs [Online], 6 | 2016, Online since 29 August 2016, connection on 10 December 2020. URL : http://journals.openedition.org/aes/757 ; DOI : https://doi.org/10.4000/aes. 757

This text was automatically generated on 10 December 2020 .

Centre de recherche LISAA (Littératures SAvoirs et Arts) 


\title{
Inhabiting Flower Worlds: The Botanical Art of Madeleine Françoise Basseporte
}

\author{
Une artiste en résidence dans le monde des fleurs: L'art botanique de Madeleine \\ Françoise Basseporte
}

Natania Meeker and Antónia Szabari

1 In a 2014 prose poem entitled The Albertine Workout, Anne Carson meditates on Marcel Proust's comparison of his beloved Albertine to a plant: “24. The state of Albertine that most pleases Marcel is Albertine asleep./25. By falling asleep she becomes a plant, he says./26. Plants do not actually sleep. Nor do they lie or even bluff. They do, however, expose their genitalia." Carson zooms in here on the Proustian scene of male voyeurism, organized around an illusion of passivity that promises the perfect availability of a delicate and intricately composed object, whether woman or plant, to the viewer. As Carson's rendering makes clear, the use of plants (most often flowers) as emblems of femininity sidesteps the question of women's sexual agency just as it engages the desires of the viewer; Albertine's sexuality - with all its ambiguities for Marcel - becomes analogous to plants' flowering (or exposure of their genitalia) - an activity that we do not really "see" for what it is even (or especially) when we look right at it. The banal comparison of a beautiful woman to a beautiful flower is a convention that denies the agency of both person and plant even while highlighting the seductive power of these seemingly passive bodies. Carson suggests that Proust conveniently "forgets" that plants in bloom, far from being asleep, are in fact actively engaged in attracting pollinators (and human beings): their allure, while not the product of an action in the human sense, is for all that not an accident. The poem transforms the figure of the plant/woman from a passive and enigmatic object into a deliberately libidinal subject, one who does not care to conceal her motives. Desire becomes a form of agency that cuts across plants and human organisms. Yet the sleeping plantlike Albertine still functions, for Marcel, as a kind of lure or bluff, projecting his own desires back to him. "Marcel appears to think he is the master of such moments", Carson writes ${ }^{2}$. The visibility of Albertine's body - 
sometimes in her sleep she throws off her covering and exposes herself to Marcel conceals not just the activity of her desire, but its logic, which is not shared by or with the spectator.

In the European context, the knowledge of sexual reproduction in plants goes back to the late seventeenth century, although the understanding of plants as having sexual distinctions is an ancient one. The eighteenth century in particular was marked by an increasing fascination, on the part of botanists and non-specialist publics alike, with the sexualization of plants, as Londa Schiebinger (among others) has brilliantly illustrated ${ }^{3}$. In what remains perhaps the best-known contribution to this widespread interest in plant sexuality, the prominent eighteenth-century botanist Carl Nilsson Linnaeus (1707-1778) developed a taxonomic system that identified plants according to their sexual organs. Linnaeus's system met with considerable success, especially in England, although its scientific legitimacy remained in dispute throughout the century (which witnessed an extraordinary proliferation of systems for botanical classification) ${ }^{4}$. Linnaeus also claimed, correctly (pace Carson), that plants too sleep, bringing them in that sense closer to our conception of an animal. Indeed, the great classificatory schemes and natural histories of the eighteenth century - including those of Linnaeus, Jussieu (1748-1836), and Buffon (1707-1788) - not only establish distinctions among various forms of being (such as the three kingdoms of nature: plant, animal, and mineral) but expose new continuities traversing these divisions. Buffon, in the "Premier discours" to the Histoire naturelle (1749), gives us this scene:

Imaginons un homme qui a en effet tout oublié ou qui s'éveille tout neuf pour les objets qui l'environnent, plaçons cet homme dans une campagne où les animaux, les oiseaux, les poissons, les plantes, les pierres se présentent successivement à ses yeux. Dans les premiers instants cet homme ne distinguera rien et confondra tout; mais laissons ses idées s'affermir peu à peu par des sensations réitérées des mêmes objets; bientôt il se formera une idée générale de la matière animée... ${ }^{5}$

In this description (prefiguring Condillac's famous statue in the 1754 Traité des sensations), the clarity and precision of the differences separating diverse beings emerge out of a state of flux and confusion; yet, as Diderot will go on to point out in his commentary on Buffon's text in the article "Animal" from the Encyclopédie, this flux can never be fully contained. In the eighteenth century, the sexuality of plantlife plays a part in this much larger debate around the status of animate and inanimate beings ${ }^{6}$. At the same time, the figure of the plant continues to function as a convenient emblem of passivity, and, in the case of flowers, of delicate femininity. The very tensions that Carson draws out in her rereading of the Proustian observer's contemplation of Albertine are already inscribed in the eighteenth-century cultural and scientific understanding of plants.

The life of Madeleine Françoise Basseporte (1701-1780), artist and scientific illustrator, nearly coincides with that of Linnaeus; she also kept up a decades-long correspondence with Buffon. At the age of forty, Basseporte succeeded Claude Aubriet (1665-1742), who was her teacher, as official painter of the Jardin du roi in 1741 and kept this position until her death in 1780. At the same time, she worked as "dessinateur" for the Académie des sciences. Before this period, from 1735 to 1741, she held the title of "peintre en mignature de sa Majesté" - a position that, while distinguished, did not come with a pension. ${ }^{7}$ She also served as a teacher to the daughters of Louis $\mathrm{XV}$, instructing them in the art of flower-painting, and may have worked for a period as the interior decorator of Madame de Pompadour. The most authoritative biographical source remains the "Notice", written by Jean Castilhon and Louis Poinsinet de Sivry ${ }^{8}$, in the 1781 volume of Le Nécrologe des 
hommes célèbres de France, par une société de gens de lettres, which was republished in the Revue universelle des arts of 1861 (volume 13). While relatively little is known about her, Basseporte was in contact with the major botanists and naturalists of her period and was recognized by those who employed her for the rigor and beauty of her illustrations of plants and, more occasionally, of shells, animals, birds, and sea creatures. In a letter written by Jussieu to Linnaeus on January 30, 1749, the former mentions that Madame Basseporte "is very proud of the title you give her, of your second wife". With its polygamic image of a fictional second marriage that evokes the sexual classifications of Linnaean taxonomy, this insider joke among botanists suggests that Basseporte had a close relationship with both Jussieu and Linnaeus, while simultaneously underlining the fact that she had no other marriage in her own life - no family or companionship that she cultivated apart from her close associations with scientists, patrons, and pupils. It also suggests that Linnaeus held Basseporte in particularly high regard.

5 If the analogy between woman and flower is on the one hand a form of longstanding and banal objectification ${ }^{10}$, on the other the putative decorousness of flower-painting allowed various seventeenth - and eighteenth-century European women illustrators, naturalists, and miniaturists a point of entry into the interconnected worlds of science, collecting, and $\operatorname{art}^{11}$. Authors like Jean-Jacques Rousseau and Erasmus Darwin encouraged women to botanize as a private hobby, and women artists like Maria Sibylla Merian (1647-1717), Elizabeth Blackwell (1707-1758), and Anne Vallayer-Coster (1744-1818), who may have been taught by Basseporte, made botanical illustration or images of flowers an important part of their œuvres. However, although women who botanized or created botanical art in the late eighteenth and the nineteenth centuries have begun to receive more attention from scholars ${ }^{12}$, the women who, like Basseporte, painted flowers along with other objects of interest for natural scientists and collectors in the earlier part of the period, remain less well-known, in part because they often worked anonymously ${ }^{13}$. In Objectivity, Lorraine Daston and Peter Galison note that the feminization of botanical illustration involved not only the daughters, wives, and sisters of male scientists but also women of modest social status who were excluded from the more prestigious genres of landscape painting or historical painting and sought a way to earn a living ${ }^{14}$. While women's pursuit of original research in the sciences was often thought to represent a challenge to conventional standards of propriety, botanical illustration was considered a relatively acceptable feminine occupation, precisely because of the ornamental attributes of the flower. The invisibility of women who engaged in this illustration was an effect of both their subordination to male scientists and the marginalization of the genre in which they worked. As Daston and Galison write, "it is more speculative but still plausible to suggest that naturalists encouraged women artists because the double inferiority of their status as artisans and as women promoted the visual and intellectual receptivity that made the illustrator, as Albinus had put it, 'a tool in my hand"'15. The Nécrologe makes clear that, in the eighteenth century, a woman illustrator like Basseporte could nonetheless gain significant social recognition. Even while laboring under the supervision of male naturalists, Basseporte was able to build networks of support and patronage for herself and her own protegés. Yet this recognition came at a price; later histories of the artists of the Jardin du roi almost invariably emphasize her inferiority to the men who held this same position (for which she was apparently paid less than her male counterparts).

Working alongside prominent scientists to illustrate the objects from the royal collections allowed Basseporte to participate in a more prestigious genre than that of flower- 
painting (in France, "peinture des fleurs"), which was a decorative art developed in seventeenth-century florilegia and pattern books ${ }^{16}$. In the Nécrologe, the authors are careful to distinguish between the practice of painting flowers and that of painting plants. As they put it:

On appelle ordinairement Peintre de fleurs, l'Artiste qui, sans étudier la fleur en elle-même, sans en détailler toutes les parties constitutives, s'attache uniquement à en rendre l'effet, \& à la peindre telle que nous la voyons. ${ }^{17}$

7 The authors go on to explain that Basseporte, rather than being a simple "Peintre de fleurs", was in fact working in the genre of "peinture des plantes", which takes a scientific approach to the beautiful objects it represents and draws our attention away from the flower and toward the structure of the plant as a whole. According to the Nécrologe, her images of plants, which allow viewers both to appreciate their beauty and to penetrate the secrets of plant physiology, stand up to comparison with those of the great Nicolas Robert (1614-1685), who painted the plants in the Jardin du roi under Louis XIV. The authors write:

Il est un genre qui, sans être moins agréable [que la peinture des fleurs], est plus utile, plus vrai, et qui ne se contente pas des formes extérieures; dans lequel la plante avec sa fleur, doit plaire comme tableau, \& se présenter comme un objet d'étude, de manière que l'illusion faite pour séduire l'Artiste même, ne cache ni ne déguise aux regards perçans du Naturaliste aucun des détails anatomiques les plus secrets de la plante: tel est le genre qu'embrassa Mademoiselle Basseporte, genre hérissé de difficultés, \& dans lequel elle a si parfaitement réussi, que les nombreux morceaux qu'elle a donnés à la Bibliothèque du roi, depuis 1732 jusqu'à sa mort, se soutiennent à côté de ceux du célèbre Robert...18

8 This comment not only aligns Basseporte with one of the most celebrated flower painters of the early modern period, but also praises her for her ability both to "please" the untrained eye with her images and to allow the naturalist access to the inner secrets of the plant itself. The beautiful flower is thus a kind of concealing illusion that allows the not so decorous nature of plant anatomy, what Carson calls plants' exposure of their genitalia, to remain veiled (even when in plain sight!). This illusion also serves to veil the artist, insofar as the plants, seashells, insects, and animals that Basseporte painted are as "naturally" alluring in their beauty and detail as they are challenging to read into or beyond.

9 The Nécrologe also refers to a comment supposedly made by Jean-Jacques Rousseau in praise of Basseporte; according to Rousseau, "la nature donnait l'existence aux plantes, mais... Mademoiselle Basseporte la leur conservait"19. This remark, if it was indeed Rousseau's, is probably in reference to Basseporte's vélins (watercolors done on vellum), of which she was obliged to produce twelve every year. 


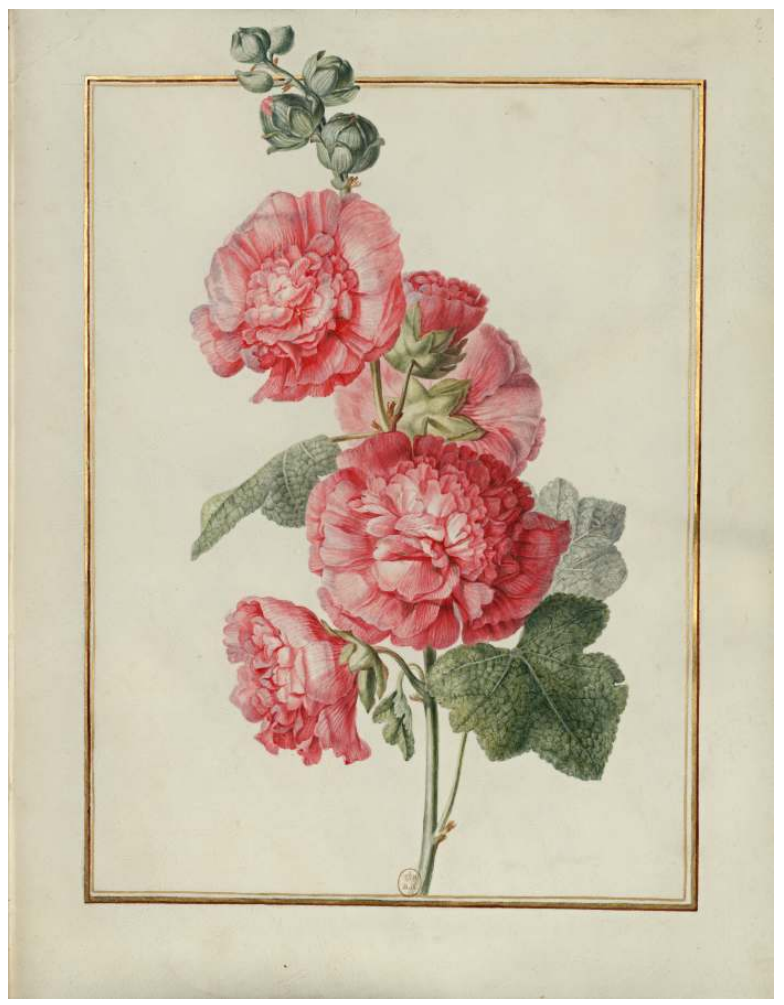

Madeleine-Françoise Basseporte. Fleurs. Gouache sur vélin, ca. 1750.

Source: Bibliothèque nationale de France, département Estampes et photographie, reserve jd- 33 -pet fol

10 Where flowers are often conventionally depicted as fragile and short-lived, this praise assigns a certain vigor to Basseporte and her art that counters the ephemerality and delicate materiality of the plants themselves. The amazing energy that appears to have characterized Basseporte's approach to her profession is in fact stressed throughout the Nécrologe, from its vivid images of her hard-working determination as a young girl copying paintings under the guidance of Robert himself, to its description of her painting flowers in the heat of the mid-day sun for Madame Pompadour, "pour saisir l'instant le plus favorable à certaines fleurs" ${ }^{20}$. Most importantly, the Nécrologe dedicates considerable space to describing Basseporte's relentless efforts to teach and support her protégé(e)s, young men and women of art and science (often in need of powerful and rich patrons) who included the anatomist Marie-Marguerite Bihéron (whose "disgust" of corpses Basseporte supposedly dispelled) and the chemist Rouelle. These accounts of (successful) patronage give us a sense of a woman actively inserting herself into networks of recognition, while also limiting these activities to the socially acceptable feminine attitudes of devotion to others and charitable self-sacrifice. Still, much of the status granted to Basseporte in the late-eighteenth-century Nécrologe will be eclipsed in the post-Revolutionary accounts of her, in part because this status seems to depend upon Basseporte's resistance to any public form of self-assertion. In the first sentence of the Nécrologe we read, "Magdelaine-Françoise Basseporte, Peintre et Dessinatrice des plantes au Jardin du Roi..., mérite une place distinguée dans le Nécrologe des Artistes et des Gens de Lettres, moins encore par ses rares talens, que par des vertus dignes de servir d'exemple aux uns et aux autres." ${ }^{11}$ If her talents are great, her selfless commitment to the advancement of her pupils (and of her art) is even greater. 
11 Her gifts as an artist and scientific observer notwithstanding, in her official capacity as "peintre du Jardin du roi" Basseporte still had her work scrutinized by Jussieu and, later, Buffon, to verify the accuracy of her images against the objects that they depicted. In this sense, her portraits of flowers, animals, and other natural objects seem, in their very commitment to regimes of classification that prioritize practices of observation, the ultimate gesture of self-effacement -the erasure, rather than the making or fashioning, of the woman artist as persona. Within the lineage of female artists and scientific illustrators, then, Basseporte stands out as both exceptional and representative. According to Anne Lafont, "La carrière de Madeleine Basseporte est doublement emblématique de la place des femmes dans les milieux des arts and des sciences du XVIII siècle: elle l'est par le caractère exceptionnel de son destin mais elle l'est tout autant par le fait que ce destin, loin d'être isolé, est comparable à celui que nombre d'autres femmes connurent à la même époque." 22 Her status as painter to the king was remarkable - and the recognition that she received from the major naturalists of her period was surely unusual - but the restrictions that came with being a "femme peintre" working in a "secondary" genre (as opposed to the more prestigious genres of landscape and history painting) were constraints that she shared with other women at the time. Despite the success she achieved over the course of her lifetime - a success for which the 1781 Nécrologe provides ample evidence - she often remains nothing more than a footnote even in histories of the "peinture des plantes", eclipsed by Robert, Aubriet, and certainly the great painter of Romantic flowers, Pierre-Joseph Redouté (1759-1840). The Mercure de France refers to her as an "Artiste distinguée" and notes the esteem in which she was held by Buffon in particular, but neither the intensity of her dedication to her work (the Mercure describes her as having died "pinceau à la main") nor the prestige of her connections, both scientific and royal, were enough to sustain her public legacy ${ }^{23}$.

Basseporte's relatively long career coincides with a widespread intensification, in France and elsewhere, of interest in the natural sciences and related disciplines - a shift that is linked to the development of new practices of observing, collecting, classifying, and experimenting with objects and their representations. As Lafont puts it, "à l'époque de la Lettre sur les aveugles de Diderot [...] la conquête du monde passait par l'observation de ses objets ou de ses specimens naturels" 24 . This "mise en ordre" of objects and forms of knowledge itself corresponds to an increasing institutionalization of science, and brings with it an emphasis on visibility as a technique and mechanism for ordering and assessing things (and persons). As Daniela Bleichmar has written in her essay on the great eighteenth-century collector and art critic Antoine-Joseph Dezallier d'Argenville, "what brought things like gardens, shells, and paintings together was a concern with visual expertise, with outlining and deploying practices of specialized diagnostic looking"25. Yet the extensive emphasis on the domain of the visual, the training of the eye that, as Bleichmar describes it, reunites scientific knowledge with new forms of connoisseurship and taste, once acquired, did not guarantee visibility to the artist and illustrator, like Basseporte ${ }^{26}$. As we can tell from an examination of the reception of Basseporte's work, both past and present, this elaborate visual culture operated based on its own economies of concealment.

13 If women illustrators participated actively in the culture of the unveiling of nature, this process obscured them and others. For instance, Anne Lafont includes her article on Basseporte in her volume likewise dedicated to Dezallier d'Argenville on the grounds of an absence of any mention of her in his writings. Lafont goes on to analyze the ambiguous 
praise Dezallier d'Argenville lavishes on women of science other than Basseporte (often but not exclusively foreigners), whom he tends to portray as both talented and unwomanly or somehow "denatured". She shows that in this way d'Argenville obeyed the socially imposed rules of decorum that demanded "modesty" from women, a demand that women themselves, who responded to the need the natural sciences created for their skills, had to develop strategies to work around. To be sure, the flowering plants that appear to make themselves infinitely available to viewers in Basseporte's images conceal a secret life of their own - one whose principles were only beginning to be understood thanks to books like Stephen Hales's Vegetable Staticks (1727) and Linnaeus's controversial Somnus plantarum (1755). It was almost exclusively male scientists who in the course of the eighteenth century acquired great prominence by studying the physiology of plants and establishing logical systems or taxonomies for describing them. (In the field of classification, the systems of Joseph Pitton de Tournefort, Jussieu, Linnaeus, and Buffon, among others, all vied for prominence with one another.) With a few notable exceptions, such as Emilie du Châtelet in France and Maria Agnesi and Laura Bassi in Italy, women received scant recognition for their work as natural philosophers, and in France were gradually shut out, over the course of the century, from institutionalized forms of training in the sciences.

Despite the difficulties they faced in gaining access both to scientific knowledge and opportunities for scientific practice, by the nineteenth century, some amateur women botanists had taken an active part in engaging with plants and, to some extent, identifying with them, as Theresa Kelley has reminded us. These women's scientific and personal investments in plants that failed to fit neatly into classificatory schemata - or otherwise seemed to push back against attempts to categorize them - allowed them to intervene in philosophical discourses that devalued women and matter in opposition to spirit, talent, and reason. As Kelley points out, plants have long served as epistemologically ambiguous objects of study, from antiquity through the Romantic era and into modernity. Like Aristotle in the $5^{\text {th }}$ century B.C.E., Linnaeus places plants between minerals and animals, an ambivalent ontological position from which they "convey a resilient hiddenness that defies the Linnaean regime of visibility" ${ }^{27}$. Kelley's work focuses on women's involvement with botanical figures that occupy a zone of epistemological instability, where both flowers and the women who studied and represented them issue an unruly challenge to efforts to contain and define their essence or nature. As Kelley writes of the nineteenth-century British women artists whom she studies: "As I read them, these botanizing women deflect normative accounts of how women could be identified with plants, in part by creating botanical figures instead of themselves becoming such figures." ${ }^{28}$ Yet it is hard to find such non-normative elements in Basseporte's flowers, both because little about her is known and because the systems of taste and scientific knowledge to which her plants seem to beautifully conform tend to eclipse any sense of individual involvement. Unlike the Romantic women whom Kelley discusses, who are singularly interested in those plants that are not fully classifiable in the Linnean system (lichens, mosses, and ferns, for example), Basseporte's flowers appear most often to confirm, rather than to strain against, both the aesthetic and scientific conventions of her time. Where Kelley's nineteenth-century women botanists tend to focus on bizarre and unusual examples, Basseporte paints those flowers that readily reflect back to the spectator the distinctions that they are meant to illustrate, as in her paintings of trees and other plants that were reproduced as engravings in the second volume of Noël-Antoine Pluche's popularizing Spectacle de la nature (1732-1750). 

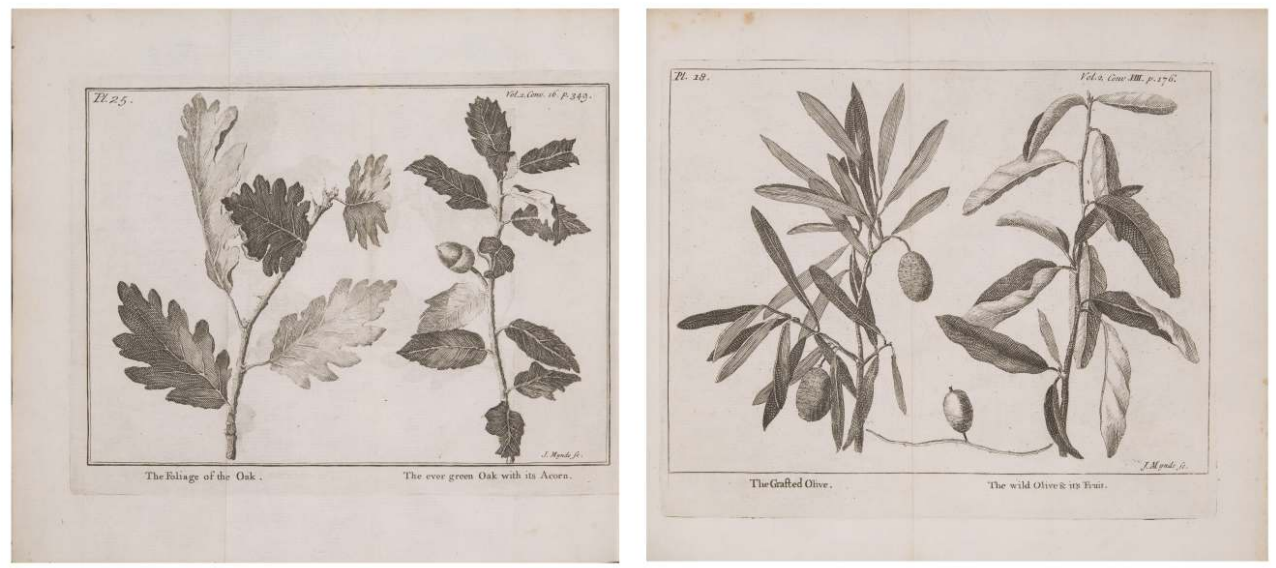

Madeleine-Françoise Basseporte. "Feuillage de chêne" et "L'Olive greffée"

Gravure de J. Mynde (English edition), in Noël-Antoine Pluche, Spectacle de la nature, Nature display'd, Vol. 2 of 7, London, J. Pemberton (et al.), 1736.

Les gravures sur cuivre de l'édition en anglais sont copiées de l'édition française originale, avec renversement des images de droite à gauche. Courtesy of University of Southern California, on behalf of the USC Libraries Special Collections.

In this sense, we are not privy, in Basseporte's images, to the artist's own encounter with the plant in its destabilizing singularity or individuality. Instead, we are left with accounts of Basseporte's attachment to her work that tend, often implicitly, to attribute to the artist herself the qualities of a plant, albeit not a seductive (and potentially maneating) plant like Proust's Albertine, but a graceful and ephemeral one. In his preface to a volume of plates entitled Les Vélins du Muséum d'histoire naturelle de Paris (published by the Librairie des Arts Décoratifs in 1928), head librarian of the museum Léon Bultingaire writes of Basseporte: "Madeleine Basseporte..., guidée par les Jussieu, appliqua une grâce aimable à toutes les tâches qui lui furent confiées." ${ }^{29}$ This description of a kind of perfect receptivity stands in contrast to Bultingaire's presentation of the other painters for the Jardin du roi, remarkable for their productivity and verve (Robert and Joubert); their travels in the company of botanists like Tournefort (Aubriet); and their ability to revitalize a fading genre (Van Spaendonck). Moreover, both women artists and scientists could be rhetorically equated with plants not only as (ideally) decorous and beautiful objects but also as fragile creatures that needed care. For example, Joseph Philippe François Deleuze, in his early-nineteenth-century history of the Musée d'histoire naturelle at the Jardin du roi, notes about Basseporte that at the end of her career "son zèle ne s'était point ralenti, mais son talent inférieur à celui d'Aubriet, auquel elle avait succédé, était encore affaibli par l'âge" ${ }^{30}$. Because Basseporte is represented here as lacking the immortal talent that Aubriet had, it is only her failing eyes and body, and her zeal, that supposedly support her artistic endeavors. This description of her inferior talent and her increasing feebleness is already very much at odds with the eighteenthcentury assessment of her incredible commitment to her work, both in the Nécrologe and the Mercure de France.

To consider Basseporte's flowers as somehow "portraits" of her is of course to continue in this tradition of conflating her persona with her objects of study, in a gesture that conceals as much as it reveals. Just as Basseporte is described by Bultingaire as most notable for her diligent willingness to accept those tasks given to her by others, her 
flowers threaten to become reflections not so much of their own "secret life", whatever this may be, as of the desires of the viewer for an unreachable interiority that the flowers refuse, in their candor, to make visible. In the Nécrologe, self-effacement is not only the effect of her keen eye for plant physiology but the symbolic gesture that inaugurates Basseporte's entry into the career of an illustrator, for she began her life as an artist producing pastel portraiture before she changed course and devoted herself to botanical and zoological drawings and paintings. (She also ornamented "objets de luxe," including clothing and porcelain-ware, as was common for the artists documenting the French royal collections). Despite the fact that Basseporte appears to have painted a self-portrait at a time when it was unusual for French women artists to do so - and despite her obvious talent for portraiture - Basseporte's work as a botanical illustrator has almost completely overshadowed her contributions to other genres, even as the act of botanical illustration is one that itself eclipses the artist (male or female) who practices it. (The pastel portrait that was traditionally considered her self-portrait has recently been reattributed to the artist Antoine Rivalz ${ }^{31}$, but another portrait whose existence is known from an entry in the inventory of her possessions after her death was probably a self-portrait painted by her $^{32}$.) The Nécrologe suggests that Basseporte abandoned portraiture in favor of illustration in order to avoid the necessity of seeking out clients, an activity that required the regular cultivation of social connections, and to find a more stable means of income to support her aging mother. Yet her self-effacement within the genre of botanical illustration is also a form of self-assertion that allows her to maintain a household and preserve a certain level of financial independence.

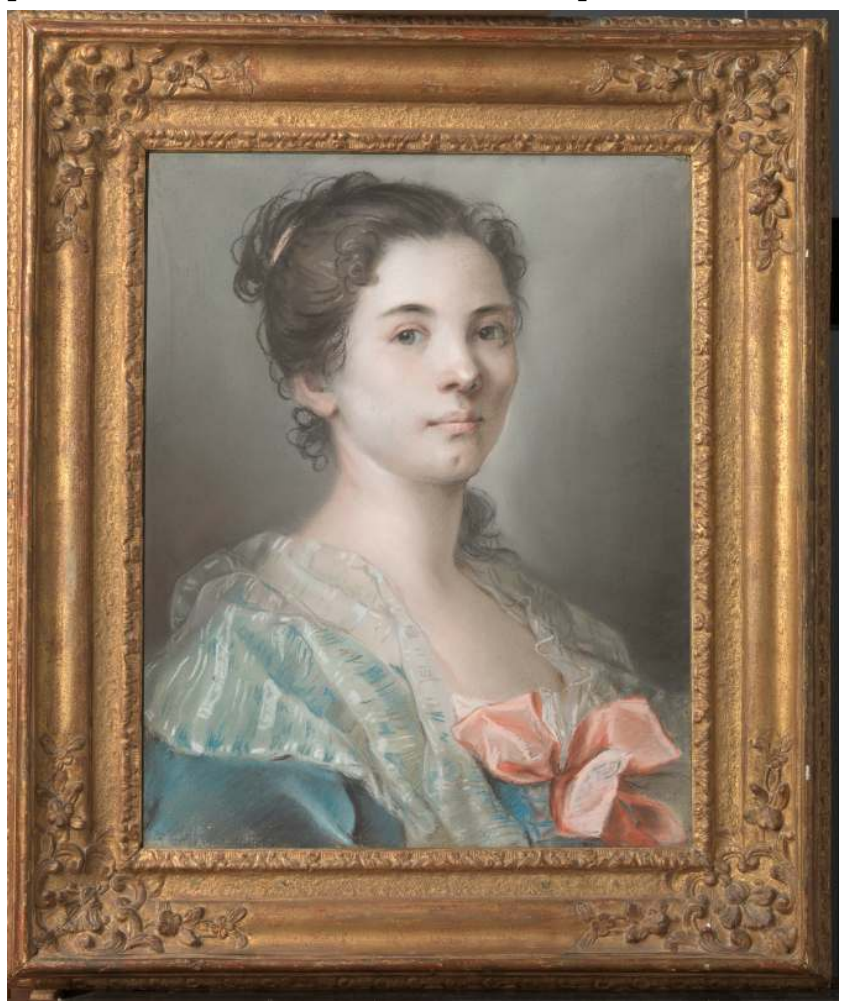

Madeleine-Françoise Basseporte, Jeune femme, ca. 1727.

SOURCE: RIJKSMUSEUM, AMSTERDAM.

In commemorating Basseporte by means of creating a social persona for her, in order to enumerate the achievements that form the basis of her social recognition, the authors of 
the entry in the Nécrologe cannot help but remark that the artistic and financial autonomy she achieved were limited, that for seven years she worked for free as a botanical illustrator for the king, and that even afterward she received a lesser pension than other (male) illustrators did. Moreover, Basseporte was never invited to join the Académie royale de peinture et de sculpture, and, while the authors state that she earned the respect of several scientists and eminent thinkers, "of foreigners visiting Paris" such as Rousseau, and of the royal family, they also indirectly tell us that she never quite got the praise she in fact deserved. Throughout, the Nécrologe celebrates Basseporte for effacing herself in acts of patronage and self-sacrifice that it interprets as testaments to her diligence and virtuous conduct toward others, including, initially, her own mother and, later, her pupils and protégés (including Anne Vallayer-Coster, a much better-known artist than Basseporte herself, who did eventually achieve membership in the Académie royale as a still-life painter). The genre of "peinture des plantes" participates in this act of self-effacement in a complex and ambivalent way, both by highlighting the supposedly feminine attributes of the artist in the images that she paints (self-sacrifice, attentiveness, care, grace) and by erasing her from the presentation of the objects on the canvas.

In his "Préface", Léon Bultingaire describes Basseporte's illustrations as "dignes à coup sûr de figurer dans les galeries d'art les plus sévères"; yet they were nonetheless never exhibited there. We can find in Bultingaire's assessment as well as in the Nécrologe an uneasy negotiation of the tension between artifice and truth ${ }^{33}$. This tension corresponds to and exacerbates the ambivalent position of the artist-as-illustrator, both present in and absent from her works. (Basseporte's style is both invisible - the mimetic representation of truth of nature visible to the scientist's mind - and somehow still striking.) On the one hand, Bultingaire affirms, we might be tempted to see the images of these plants as renderings of "les fantaises les plus osées". However, as he reassures us, we in fact find in these paintings not an "effort de stylisation" - the product of artifice detached from its objects, in other words - but a "rigoureuse exactitude" which is protected from disfiguration by the seriousness and observational precision of the artists themselves (who are distinctive precisely for their ability to erase themselves from the scene of the object). At the same time, Bultingaire portrays the flowers on the canvas as if they were human subjects, writing of their seductive manner and their graceful attitudes. In fact, it is not enough to say that his language implies an anthropomorphic dimension to these "portraits"; Bultingaire's "flowery" rhetoric stresses the fulsome femininity of their "modèles," who lend themselves so readily to observation. Similarly, the Nécrologe plays on the division between "illusion" and physiological accuracy that Basseporte's images seem to navigate so handily, even while intimating that Basseporte's paintings are most valuable as signs of her virtuous dedication to the welfare of others. In an economy of truth and artifice, science and art, authority and seduction, she remains awkwardly positioned between the two terms.

Basseporte's visibility-in-invisibility (her authority as a painter of nature in its most "scientific" of attitudes) is an inversion of the position of the plant as object of our gaze, its invisibility-in-visibility. The flower, in the most successful botanical illustrations, pleases the eye "comme tableau," at the same time as it offers up to the "regard perçant du naturaliste" the most intimate of its secrets. In this contrast between the flower's capacity to induce pleasure with its grace and to satisfy scientific curiosity with the exposure of its secrets to the naturalist's curious eye, we find plantlife portrayed as both 
attractive and enigmatic. We might also find, in the ability of the flower both to stimulate and to evade the curiosity of the scientist, an echo of the Encyclopédie's claim that "l'organisation d'une plante est un arrangement de filets si déliés, de corpuscules si minces, de vaisseaux si étroits, de pores si serrés, que les modernes n'auroient pas été fort loin sans le secours du microscope" ${ }^{34}$. The smallness and delicacy of plants - the mysterious order of their inner nature - makes them both difficult to penetrate and the ideal object of scrutiny. In this, of course, they come once again to resemble the figure of a woman. Their intricacy draws us in, but even the act of identifying plant structures does not necessarily bring us nearer to understanding their functions, insofar as the latter do not involve or require us.

In reading Basseporte's flower paintings as particularly decorous - even in the "naturalism" of their renderings - and in collapsing her eminent career as an illustrator into a model of feminine generosity (to her mother, to other artists, to her patrons), we find ourselves once again taking up the position that the work women do with and on flowers involves a kind of mise en abyme of feminine attributes, wherein both the flower and the female botanist acquire each other's qualities, in a closed economy of ornamental intimacy. Women's relationship to botany - as expressed in images like Basseporte's flower paintings - thus seems to provide the counterpoint - or the antidote - to a destabilizing botanical imaginary in which the dividing line between plant and animal is shifting, with sometimes alarming results. Basseporte, like the plants themselves, seems to "reveal" her secrets best in the (selfless) act of never having told them, a silence that cannot for all that be called a lie. Nothing about Basseporte's botanical works suggests an autobiographical preoccupation on the part of the painter; yet the flowers themselves are persistently read through both the painter's absence - Basseporte effaces herself before nature - and through her insistent presence - the flowers stand as a sign of Basseporte's virtuous femininity, of the "local" world consisting of the king's residences, libraries, her deserving but poor protégés, and, until her death, her mother, to whom she was devoted. She is "in them" through the observation and painstaking depiction that they manifest, as a hard-working artist-artisan who participates in - but does not shape - the modes of production that shore up the French monarchy in the eighteenth century or as a virtuous woman who nurtures nature in its capacity of pushing life to its limit, in its manifestations of finitude. The Nécrologe, written at a moment shortly after her death, strives then once again to contain and present these local worlds - from the plants she observed, to the family she sustained, to the elite society in which she circulated - that were her diligent life-long care.

Basseporte, who has received recognition largely for the moments at which she withdraws from forms of self-assertion and self-representation, is for this reason paradoxically identified with the images of plants (and, to a lesser extent, animals and shells) that she produced and with the physical and affective expenditure needed to produce them. As contemporary critics of her work and of her legacy, we need to question this identification, but not necessarily to refuse it entirely. The eighteenthcentury attraction to botany and botanical inquiry coincides with a rise of interest in the plant as a creature that unsettles as well as confirms our assumptions about the differences among various forms of life. Moreover, the materialist consideration of the human being as one animal among others runs alongside the revitalization of the plant as an animate being in its own right. The comparison of women to plants can clearly function in damaging and misogynist ways, just as the association of women with flowers 
can be (and was) used to justify their subordinate status in a wide range of contexts. On the other hand, if the perception of botanical artists like Basseporte can be said to be (problematically) intertwined with the perception of their objects of study (including flowers and plants), we can also find, in the story of her life told by Nécrologe, an openness to a representation of Basseporte as something other than an underrecognized illustrator, toiling in relative obscurity until her abilities failed her, of small creatures and small objects. In the Nécrologe's emphasis on her unusual strength, her diligence, and her success as a teacher, another portrait of Basseporte emerges, one that moves us away from the question of the circulation of her name (or image) and toward that of the enduring effects of her work - on her pupils, on her friends, and on the community of naturalists that she seems to have cultivated with success. Her relative visibility is not an index of her relative significance within the worlds she helped construct. In this way, perhaps her legacy indeed retains something vigorously plantlike about it. Regimes of visibility can seem to entrap both woman artist and plant in an economy of decorous (or, in the case of Proust's flowers, indecorous) self-display. At the same time, Basseporte's flower paintings serve as emblems of an impressive capacity to prosper and endure in often unpropitious circumstances.

\section{NOTES}

1. Anne Carson, The Albertine Workout, New Directions Poetry Pamphlet \#13, New York, New Directions Publishing Corporation, 2014, p. 10.

2. Carson, op. cit., p. 11.

3. See Londa Schiebinger, Nature's Body: Gender in the Making of Modern Science, Boston, Beacon Press, 1993, in particular Chapter 1, on "The Private Lives of Plants," for a by-now classic account of this phenomenon. Schiebinger's Plants and Empire: Colonial Bioprospecting in the Atlantic World Cambrige, Massachusetts, Harvard University Press, 2004, examines the place of gender relations in the "global culture of botany" that develops during the eighteenth century. Schiebinger writes that "Plant sexuality exploded onto the scene in the seventeenth and eighteenth centuries." (19)

4. Schiebinger notes, "By the middle of the eighteenth century, the sexualist metaphor had swept the botanical world, except for France" (Nature's Body, 29). For an analysis of the French reception of Linnaeus in the later part of the eighteenth century, see Pascal Duris, Linné et la France: 1780-1850, Geneva: Droz, 1993.

5. Georges-Louis Leclerc de Buffon, Histroire naturelle, in Euvres, Stéphane Schmitt and Cédric Crémière eds., Paris: Gallimard, 2007, p. 47.

6. In France, see Julien Offray de la Mettrie's L'Homme-plante (1748), a treatise playing on the famous analogy established in L'Homme-machine in which he discusses similarities between plant and human sexuality.

7. Aline Hamonou-Mahieu, Claude Aubriet: Artiste naturaliste des Lumières, Paris, Comité des travaux historiques et scientifiques, 2010, p. 81; quoted in Anne Lafont, "Basseporte", 1740, Un abrégé du monde: Savoirs et collections autour de Dezallier d'Argenville, Anne Lafont ed., Lyon, Fage éditions, 2012. 
8. According to the "Nouvelles littéraires" section of the June 20, 1781 edition of the Mercure de France, which reviewed volume 16, in which Basseporte's entry appears.

9. James Edward Smith, A selection of the correspondence of Linnaeus and other naturalists, from the original manuscripts, vol. 1, London, 1821, p. 221. Schiebinger notes of this same passage that Linnaeus "simply tended to see anything female as a vif", Nature's Body, $\mathrm{n}^{\circ} 26$.

10. For a feminist analysis of this analogy in philosophical context, see in particular Elaine P. Miller's valuable study of the relationship between nineteenth-century philosophies of vegetal life and femininity, The Vegetative Soul: From Philosophy of Nature to Subjectivity in the Feminine, Albany, New York, SUNY Press, 2002. More recently, Michael Marder has examined the plant as a philosophical figure of a non-oppressive ethical subjectivity characterized, among other things, by "atelic dispersion", taking us outside the binary logic of active/passive beings. Michael Marder, Plant-Thinking: A Philosophy of Vegetal Life, New York: Columbia University Press, 2013, p. 181.

11. For an excellent overview of an important moment in the development of this culture of collecting, classifying, and observing, see 1740, Un abrégé du monde. Savoirs et collections autour de Dezallier d'Argenville, Anne Lafont ed., Lyon, Fage éditions, 2012. For a perceptive account of connoisseurship and scientific observation in Dezallier d'Argenville's milieu, see Daniela Bleichmar, "Learning to Look: Visual Expertise across Art and Science in Eighteenth-Century France", in Eighteenth-Century Studies 46.1, fall 2012, p. 85-111.

12. In the British context, see in particular Theresa M. Kelley, Clandestine Marriage: Botany and Romantic Culture, Baltimore, MD, Johns Hopkins University Press, 2012; Sam George, Botany, Sexuality, and Women's Writing 1760-1883: From Modest Shoot to Forward Plant (Manchester: Manchester University Press, 2007) and Ann Shteir, Cultivating Women, Cultivating Science: Flora's Daughters and Botany in England, 1760-1860 (Baltimore: Johns Hopkins University Press, 1996).

13. Maria Sibylla Merian is an exception to this general rule. See Janice Neri's The Insect and the Image: Visualizing Nature in Early Modern Europe, 1500-1700, Minneapolis: University of Minnesota Press, 2011 for a perceptive study of Merian that discusses among other topics the Neues Blumenbuch (1675), Merian's first illustrated publication consisting of floral designs for use as needlework patterns. In Catching Nature in the Act: Réaumur and the Practice of Natural History in the Eighteenth Century, Chicago: University of Chicago Press, 2014, Mary Terrall includes a fascinating discussion of Hélène Dumoustier, who made thousands of drawings for R.A.F. de Réaumur, and whom he did not name in print (although he made her his heir).

14. Lorraine Daston and Peter Galison, Objectivity, New York: Zone Books, 2007, p. 89.

15. Daston and Galison, op. cit., p. 89.

16. For an overview of the different techniques of flower-painting, see Gill Saunders, Picturing Plants: An Analytical History of Botanical Illustration, Berkeley, University of California Press, 1995.

17. Castilhon and Sivry, "Notice sur Mademoiselle Basseporte, peintre du roi" in Nécrologe des hommes célèbres de France, par une société de gens de lettres, vol. XVI (Paris: Chez Moutard, 1781), p. 159-187, p. 162-163. See also "Mademoiselle Basseporte, peintre", in the Revue universelle des arts, vol. 13, Paris: Veuve Jules Renouard, 1861, p. 139-147.

18. Nécrologe, op. cit., p. 163-164.

19. Ibid., p. 170.

20. Ibid., p. 168.

21. Ibid., p. 159-160.

22. Lafont, "Basseporte", in Un abrégé du monde, op. cit., p. 58.

23. Mercure de France, p. 226.

24. Lafont, Introduction, Un abrégé du monde, op. cit., p. 8.

25. Bleichmar, “Learning to Look...”, op. cit., p. 87.

26. The problem of the invisibility of the woman artist, who might be employed for her skill but remained unrecognized for her genius, was faced by women working in a variety of genres, and 
not just botanical illustration. See, for instance, Melissa Hyde's discussion of the miniatures produced by the artists working for the Menus-Plaisirs in her article "Women and the Visual Arts in the Age of Marie-Antoinette", in Anne Vallayer-Coster: Painter to the Court of Marie Antoinette, Eik Kahng ed., New Haven, Yale University Press, 2002. For the exclusion of women from the discourse of creative genius, see in particular the essay by Hyde in this volume and Mary D. Sheriff's "The Woman-Artist Question," in Royalists to Romantics, ed. Jordana Pomeroy, Washington, D.C., National Museum of Women in the Arts, 2012.

27. Kelley, op. cit., p. 5.

28. Ibid., p. 93.

29. Léon Bultingaire, "Préface," n.p.

30. Joseph Philippe François Deleuze, Histoire et description du Muséum de l'histoire naturelle, Paris, Roye, 1823, p. 54.

31. The reattribution was made on the basis of a print identified as a portrait of Rivalz's wife, showing the same woman in the same pose as appears in the pastel once thought to be of Basseporte. It was listed as by Rivalz at Christie's Paris sale of Old Master Drawings on April 1, 2011, lot 76. We thank Sarah Vowles for this information.

32. See Melissa Hyde's article in this volume. We thank Melissa Hyde for her especially illuminating discussion, in private correspondence, of the inventory of Basseporte's paintings held in the Archives nationales, and listed in Neil Jeffares, "Madeleine-Françoise Basseporte", Dictionary of Pastellists before 1800, London, 2006, online edition www.pastellists.com/Articles/ Basseporte.pdf, accessed/update July 13, 2015.

33. Daston and Galison underscore that the true-to-nature tradition of scientific illustration in which Basseporte, along with other early modern illustrators, worked introduces an element of artifice in the truthful depiction of natural objects, which are not shown exactly as they are seen in nature but in an idealized form that best reveals their essence. While artists (who were often women) had to create these representations, the rational idea of the object was supposed to belong to the scientist, who had to control the artist and keep any flights of fancy in check.

34. Antoine-Joseph Dezallier d'Argenville and Denis Diderot, “Anatomie de Plantes", Encyclopédie, ou dictionnaire raisonné des sciences, des arts et des métiers, etc., Denis Diderot and Jean le Rond d'Alembert. eds., University of Chicago, ARTFL Encyclopédie Project, Spring 2013, Robert Morrissey ed, http://encyclopedie.uschicago.edu/, vol. 1, p. 437.

\section{ABSTRACTS}

In "Inhabiting Flower Worlds", Meeker and Szabari examine the production and reception of botanical illustrations by Madeleine Françoise Basseporte (1701-1780). The article presents the relationship between image and artist as a form of visibility-in-invisibility - a chiasmic reversal of the invisibility-in-visibility of plants, long thought to conceal a hidden life. Basseporte's oeuvre attests both to the marginalization of woman illustrators typical of the period and to the vivacity of a woman artist who achieved relative fame under unfavorable conditions.

Dans cet article, Meeker et Szabari examinent la production et la réception des illustrations botaniques de Madeleine Françoise Basseporte (1701-1780). Elles présentent la relation entre image et artiste comme une forme de visibilité dans l'invisibilité - un renversement en chiasme de l'invisibilité des plantes, dont on a longtemps pensé qu'elles recélaient une vie cachée, en 
visibilité. L'œuvre de Basseporte atteste à la fois la marginalisation des femmes illustratrices caractéristique de la période et la vivacité de la femme artiste qui a obtenu une certaine gloire dans des conditions défavorables.

INDEX

Mots-clés: Basseporte (Madeleine Françoise), illustration botanique, la vie des plantes, visibilité, femmes artistes

Keywords: Basseporte (Madeleine Françoise), botanical illustration, plantlife (theories of), visibility, women artists

\section{AUTHORS}

\section{NATANIA MEEKER}

University of Southern California

\section{ANTÓNIA SZABARI}

University of Southern California 